\title{
ANALISIS KONTRASTIF BAHASA LIO-INDONESIA \\ DAN PENGIMPLEMENTASIANNYA \\ DALAM MODEL PEMBELAJARAN BAHASA KEDUA
}

\author{
Suhardi dan Pujiati Suyata \\ FBS Universitas Negeri Yogyakarta (e-mail: suhardi@uny.ac.id; \\ HP 08157918974)
}

\begin{abstract}
A Contrastive Analysis of the Lio and Indonesian Languages and Its Implementation in a Second Language Learning Method. This study aims to identify linguistic characteristics of the Lio and Indonesian languages and employ them in a second language learning model. This study employed an R \& D approach consisting of two stages: linguistic characteristic identification and implementation in a second language learning model. The data in the first stage were collected through observations, discussions, and interviews. The contrastive analysis using the synchronic method was done to analyze them and those from the focus group discussions were analyzed using the qualitative descriptive technique. The data from the second stage were analyzed using the quantitative technique. The results are as follows. First, both languages have similarities in terms of the phoneme system and phrase and sentence structures. Therefore, the students with the Lio language and culture background find it easy to learn Indonesian in the beginner stage. Second, both languages have similarities in phrase structure, i.e. H$\mathrm{M}$ and M-D, and in sentence structure, i.e. SVO. Third, because of such similarities, a contrastive learning model is appropriate for the Indonesian language learning in the beginner stage for the students with the Lio language and culture background.
\end{abstract}

Keywords: contrastive analysis, second language learning model

\section{PENDAHULUAN}

Bhineka Tunggal Ika sebagai lambang Negara Kesatuan Republik Indonesia(NKRI)mengisyaratkan adanya kebervariasian budaya, adat istiadat, dan bahasa yang digunakan. Peta Bahasa Nasional melaporkan jumlah bahasa daerah di Indonesia lebih dari 450 buah, belum termasuk bahasa-bahasa yang ada di Papua yang menurut perhitungan terakhir sekitar 350 buah. Selain bahasa daerah, ada bahasa Indonesia yang digunakan secara nasional dan ditetapkan sebagai bahasa pengantar di seko- lah-sekolah (Undang-Undang Pendidikan, No. 20 Tahun 2003).

Ciri-ciri kebahasaan bahasa Indonesia dan bahasa daerah dimungkinkan berbeda, demikian pula antara bahasa daerah satu dengan yang lain. Menurut Blust, seorang ahli perbandingan bahasa Austronesia, bahasa-bahasa di wilayah Indonesia termasuk dalam kelompok bahasa Melayu Polinesia (MP). Berdasarkan ciri-ciri kebahasaan, bahasa MP dibedakan atas MP Barat dan MP Timur, sementara MP Timur dibedakan atas MP Tengah dan MP Timur. Bahasa 
Lio sebagai salah satu bahasa daerah di Flores termasuk MP Tengah. Dalam hal pembelajaran bahasa, berbedaan ciriciri kebahasaan, baik antar-bahasa daerah maupun antara bahasa daerah dan bahasa Indonesia menyulitkan guru.

Bahasa Indonesia sebagai bahasa pengantar di sekolah perlu dikuasai dengan baik oleh siswa. Terganggunya kondisi tersebut akan menghambat penyerapan materi pelajaran di sekolah. Oleh karena itu, penguasaan bahasa Indonesia menjadi kunci utama keberhasilan pembelajaran. Persoalannya, oleh karena bahasa Indonesia harus diajarkan dengan bahasa pengantar bahasa Indonesia, siswa yang bahasa pertamanya (B1) bahasa daerah harus belajar dua kali, pertama memahami bahasa pengantarnya dan kedua belajar bahasanya (B2). Hal itu menyulitkan siswa, terutama siswa di daerah pinggiran dan pedalaman yang belum menguasai bahasa Indonesia (B2).

Kesulitan berikutnya adalah ketika guru menggunakan bantuan bahasa daerah untuk memasukkan pemahaman bahasa Indonesia, tidak semua guru menguasai bahasa daerah yang dikenal siswa, khususnya guru-guru yang datang dari luar daerah. Di Flores, kebanyakan guru berasal dari luar daerah. Guru-guru pendatang tersebut mengalami kesulitan mengajarkan bahasa Indonesia dengan bahasa pengantar bahasa Indonesia, karena siswa belum menguasai dengan baik bahasa pengantar tersebut. Di pihak lain, mereka juga sulit mengajarkan dengan bahasa pengantar bahasa daerah karena mereka tidak menguasai bahasa daerah siswa.
Analisis kontrastif antarbahasa dapat dilakukan untuk menjembatani kesulitan tersebut. Perlu dilakukan perbandingan secara sinkronis antarbahasa, misalnya bahasa Indonesia dengan bahasa Lio. Dalam kalimat bahasa Lio, "Aku seo moko.", dapat diterjemahkan per kata oleh siswa menjadi " Aku goreng pisang." Analisis kontrastif akan menemukan bahwa penggunaan bahasa Indonesia, "goreng" dalam kalimat tersebut tidak tepat karena dalam bahasa Indonesia kata kerja yang benar sesuai dengan konteks kalimat yang bersangkutan adalah "menggoreng". Hal ini terjadi, karena dalam bahasa Lio tidak dikenal afiks untuk membentuk kata jadian, sedangkan dalam bahasa Indonesia hal tersebut terjadi. Dengan analisis kontrastif, ciri kebahasaan antarbahasa yang dibandingkan dapat diketahui, dan hal itu akan memudahkan guru dalam mengajarkan bahasa kedua (B2) bagi siswanya.

Berdasarkan latar belakang tersebut, permasalahan yang dikaji dalam tulisan ini adalah (1) perbedaan karakterisktik kebahasaan antara bahasa Indonesia dan Lio; (2) pengembangan model pembelajaran bahasa yang berbasis perbedaan karakteristik kebahasaan antara bahasa Indonesia dan Lio. Atas dasar masalah tersebut, tujuan kajian ini adalah (1) teridentifikasinya perbedaan karakteristik kebahasaan antara bahasa IndonesiadanLio; (2) ditemukannya model pembelajaran bahasa kedua bagi penutur bahasa dan budaya Lio. Sementara itu, manfaat hasil kajian ini ada beberapa poin. Pertama bagi guru, hasil kajian ini bermanfaat untuk praktik pembelajaran bahasa Indonesia sebagai 
bahasa kedua (B2) di kelas, terutama bagi sekolah yang bahasa pertama (B1) siswanya bermacam-macam. Kedua bagi calon guru, hasil kajian ini menambah dan memperluas konsep pembelajaran bahasa Indonesia di sekolah. Ketigabagi Depdiknas, penelitian ini memberikan manfaat bagi peningkatan mutu pendidikan di Indonesia secara keseluruhan. Keempat bagi masyarakat Indonesia, hasil kajian ini bermanfaat dalam upaya menyatukan dan membangun bangsa, yang berawal dari studi bahasa, menuju ke integrasi bangsa dan harmoni sosial.

\section{METODE}

Pendekatan penelitian ini adalah research and development $(R \mathcal{E} D)$. Borg dan Gall mengatakan "educational research and development $(R \mathcal{E} D)$ is a process used to develop and validate educational production". Pendekatan tersebut dilakukan dalam dua tahap. Pada tahap I dilakukan survei lapangan, yakni wilayah Flores Barat, NTT. Dalam survei tersebutdilakukan analisis kontrastif antara bahasa Indonesia-Lio (Flores). Hasil survei menjadi masukan bagi pengembangan model pembelajaran multikultural. Indikator ketercapaian tahap I adalah teridentifikasinya perbedaan karakteristik bahasa Lio-Indonesia.

Pada tahap II dilakukan survei kepustakaan, dilanjutkan dengan focus group discussion ahli (FGD I) untuk menemukan indikator model kulturalisme dalam pembelajaran yang sesuai. Berdasarkan indikator yang ada, dikembangkan model hipotetik pembelajaran yang dimaksud. Langkah berikutnya adalah diskusi model dengan melibat- kan ahli (FGD II) untuk memantapkan draf model yang dikembangkan. Validasi model dilakukan secara terbatas, dengan melakukan eksperimen pembelajaran di kelas. Hasil validasi dianalisis dengan melibatkan ahli untuk menetapkan model yang diinginkan. Indikator ketercapaian tahap II adalah ditemukannya model multikulturalisme dalam pembelajaran bahasa.

Subjek penelitian pada tahap I adalah penutur asli bahasa Lio, sedangkan subjek penelitian pada tahap II adalah guru dan siswa kelas I SD. Dari penutur asli digali data kebahasaan yang berupa kosakata, frasa, dan kalimat yang digunakan sebagai alat komunikasi masyarakat. Guru dan siswa kelas I SD digunakan untuk uji coba model pembelajaran. Teknik pengambilan sampel dilakukan secara bertujuan, yakni SD yang termasuk kategori 'sedang'.

Informan penelitian ini ada empat orang, yakni tiga orang sebagai informan utama dan satu orang sebagai informan pendamping. Informan tersebut adalah penutur asli bahasa Lio di Flores Barat yang ditentukan atas dasar kriteria: (1) umur antara 30 - 50 tahun atau lebih, laki-laki atau perempuan yang alat ucapnya baik dan dapat berbicara jelas; (2) bekerja sebagai petani, pedagang kecil atau jenis pekerjaan lain yang jarang meninggalkan rumah; (3) berpendidikan sekolah dasar atau lanjutan; (4) lahir dan dibesarkan di daerah itu dan jarang meninggalkan kampung halamannya; dan (5) dapat berbahasa Indonesia.

Instrumen penelitian tahap I adalah daftar tanyaan kosakata, frasa, dan kalimat. Daftar tanyaan kosakata terdiri 
atas 600 kosakata, terbagi dalam 16 medan, yakni (1) bilangan; (2) waktu dan musim; (3) ukuran; (4) bagian tubuh; (5) kata ganti orang dan sapaan; (6) istilah kekerabatan; (7) pakaian dan perhiasan; (8) binatang; (9) tumbuhan; (10) alam dan benda alam; (11) rumah dan bagiannya; (12) alat-lat rumah tangga; (13) arah dan petunjuk; (14) aktivitas seharihari; (15) keadaan dan warna; dan (16) pekerjaan dan jabatan. Daftar tanyaan tersebut diambil dari Dhanawati (2002) dengan modifikasi sesuai dengan tujuan penelitian. Dari penelitian terdahulu, terbukti bahwa daftar tanyaan tersebut valid untuk penelitian jenis ini.

Daftar tanyaan frasa berjumlah 100 yang aplikasinya dikemas dalam bentuk kalimat atau cerita, sementara daftar tanyaan kalimat berjumlah 100 juga yang aplikasinya berupa cerita atau dialog-dialog ringan. Untuk mengetahui bagaimana frasa dan kalimat dalam tuturan yang lebih luas, informan diminta untuk bercerita atau bercakap-cakap dengan temannya, atau dipancing dengan pertanyaan-pertanyaan yang jawabnaya berupa wacana yang cukup luas.

Pada tahap I, diterapkan metode langsung (metode lapangan) karena metode ini lebih tinggi derajat keilmiahannya daripada metode tidak langsung. Data diambil dengan cara (1) cakap dengan teknik cakap semuka (wawancara), (2) simak dengan teknik simak lebat cakap dan simak bebas libat cakap. Data yang diperoleh dengan metode simak digunakan untuk validasi data yang diperoleh dengan metode cakap, sekaligus melengkapi data yang tidak dapat diungkap lewat daftar tanyaan. Sementara itu, pada tahap II, data dikumpulkan melalui observasi, diskusi, dan wawancara. Data hasil observasi divalidasi dengan data hasil diskusi dan wawancara yang sekaligus untuk melengkapi data yang tidak dapat diungkap dengan observasi.

Analisis data hasil studi tahap I, yaitu analisis kontrastif yang dilakukan secara deskriptif komparatif dengan menggunakan metode sinkronis. Datadata kebahasaan yang diperoleh diamati, dibandingkan satu dengan yang lain untuk menemukan perbedaan karakteristik bahasa-bahasa yang diteliti. Pada tahap II, data hasil FGD dianalisis secara deskriptif kualitatif, sementara data hasil validasi model dianalisis dengan teknik kuantitatif.

\section{HASIL DAN PEMBAHASAN}

Analisis Kontrastif Bahasa Indonesia Lio

Secara historis komparatif, bahasa Lio di Flores Barat termasuk kelompok bahasa MP Tengah, sedangkan salah satu bahasa yang tergolong MP Timur adalah bahasa Tha di Papua. Dalam hal ini, bahasa Melayu termasuk kelompok Austronesia Barat. Sementara itu, bahasa Indonesia yang merupakan perkembangan dari bahasa Melayu tergolong pula pada kelompok Austronesia Barat.

Lio adalah salah satu bahasa daerah di Flores Barat, tepatnya bahasa Lio berada di Kabupaten Ende. Di Kabupaten Ende terdapat dua etnik, yakni Etnik Lio dan Etnik Ende. Etnik Lio menggunakan bahasa Lio, sedangkan Etnik Ende menggunakan bahasa Lio-Ende. Pemakai bahasa antara kedua etnik tersebut saling memahami karena kedua dialek tersebut serumpun dan kedua- 
nyamerupakan keturunan Proto Austronesia.

Korespondensi bunyi di antara dialek Lio dan dialek Lio-Ende bersifat teratur (Mbete dkk., 2006:143). Namun, di antara kedua dialek tersebut juga memiliki perbedaan, baik pada tataran fonetik maupun leksikon. Perhatikan perbandingan berikut.

$\begin{array}{lll}\begin{array}{l}\text { Dialek Lio } \\ \text { aku }\end{array} & \begin{array}{l}\text { Dialek Lio-Ende } \\ \text { ja'o }\end{array} & \text { 'saya, aku' } \\ \text { mera } & \text { tazo } & \text { 'merah' } \\ \text { roke } & \text { nonde } & \text { 'tidur' } \\ \text { dowa } & \text { peka } & \text { 'sudah' } \\ \text { gha } & \text { ndia } & \text { 'sini' } \\ \text { ria } & \text { meze } & \text { 'besar' }\end{array}$

Bahasa Lio seperti halnya bahasa Lio-Ende memiliki 5 vokal (i, e/E, o, u, a) dan 22 konsonan (p, t, k, b, d, g, mb, nd, ngg, bh, dh, gh, m, n, ng, l, r / , s, j, f, $h$, dan w). Bahasa Lio ini tergolong bahasa vokalis, yakni semua vokal dapat berposisi akhir sebagai penutup kata, kecuali pepet yang hanya muncul pada posisi awal dan tengah kata. Dengan kata lain, tidak ada konsonan yang verposisi pada akhir kata.

Bahasa Lio memiliki pola persukuan terbuka. Kata-kata bahasa Lio dibangun atas dua pola suku kata, yakni pola V dan KV. Kata-kata pada bahasa Lio dapat terdiri atas satu sampai dengan lima suku kata. Pola kata dwisuku merupakan pola kata yang sangat dominan. Selain itu, bahasa Lio memiliki pola-pola pemajemukan, perulangan, kalimat dasar, kalimat turunan, kalimat tunggal, dan kalimat majemuk.

Bahasa dalam satu kelompok tentu banyak kemiripan, selain perbedaan, seperti bahasa Indonesia dan Lio. Hal tersebut terungkap dari hasil survei ten- tang kedua bahasa tersebut. Berikut dipaparkan perbedaan dan kemiripan antara bahasa Indonesia dan Lio, baik dalam hal fonem-kosakata, kelompok kata (frasa), maupun struktur aklimat.

\section{Tataran Fonem-Kosakata}

Berdasarkan data yang diperoleh, dapat dibandingkan fonem bahasa Indonesia dan Lio yang dapat dilihat pada Tabel 1 berikut.

Tabel 1: Perbandingan Fonem Bahasa Indonesia-Lio

\begin{tabular}{|c|c|c|}
\hline $\begin{array}{l}\text { Bhs. Induk } \\
\text { Austronesia }\end{array}$ & $\begin{array}{c}\text { Bahasa } \\
\text { Indonesia }\end{array}$ & $\begin{array}{c}\text { Bahasa } \\
\text { Lio }\end{array}$ \\
\hline *a & a & $\mathrm{a}$ \\
\hline${ }^{*} \mathrm{~b}$ & $b$ & b-; mb-; bh- \\
\hline${ }^{*} \mathrm{c}$ & c & - \\
\hline *d & d-; -d- & d-; nd-; dh- \\
\hline * & ә & - ə-; e- \\
\hline * $g$ & $\mathrm{~g}-;-\mathrm{g}-;-\mathrm{k}$ & g-; gh-; ngg- \\
\hline${ }^{*} \mathrm{~h}$ & (h)- & (h)- \\
\hline * $\mathrm{i}$ & i & i-; -E- \\
\hline$* j$ & j- & j- \\
\hline${ }^{*} \mathrm{k}$ & k & $\mathrm{k}$ \\
\hline$* 1$ & 1 & 1 \\
\hline${ }^{*} \mathrm{~m}$ & $\mathrm{~m}$ & $\mathrm{~m}$ \\
\hline * $\mathrm{n}$ & $\mathrm{n}$ & n; ng- \\
\hline${ }^{*} \mathrm{O}$ & o & o \\
\hline${ }^{*} \mathrm{p}$ & $\mathrm{p}$ & $\mathrm{p}$ \\
\hline${ }^{*} q$ & $\mathrm{~h}$ & - \\
\hline${ }^{*} \mathrm{R}$ & $\mathrm{r} ;-\mathrm{r}$ & $\mathrm{r}-/-\mathrm{z} ;-^{*} \mathrm{R}$ \\
\hline$* r$ & $\mathrm{r}$ & - \\
\hline *s & $\mathrm{s}$ & $\mathrm{s}$ \\
\hline${ }^{*} \mathrm{~T}$ & $\mathrm{t} ;-\mathrm{t}$ & - \\
\hline$* t$ & $\mathrm{t}$ & $\mathrm{t}-$ \\
\hline *u & $\mathrm{u}$ & $\mathrm{u}$ \\
\hline${ }^{*} \mathrm{~W}$ & $\mathrm{w}$ & $\mathrm{W}$ \\
\hline * ay & ai & - \\
\hline * au & $\mathrm{au}$ & aw \\
\hline${ }^{*}$ uy & $\mathrm{u}$ & - \\
\hline
\end{tabular}


Tabel di atas menunjukkan bahwa ada persamaan fonem antara bahasa Indonesia dan bahasa Lio. Di samping itu, ada beberapa fonem yang berbeda antara kedua bahasa tersebut, seperti tampak pada Tabel 2 berikut.

\section{Tabel 2: Analisis Kontrastif Fonem Bahasa Indonesia-Lio}

\begin{tabular}{|c|c|c|}
\hline $\begin{array}{l}\text { Bhs. Induk } \\
\text { Austronesia }\end{array}$ & $\begin{array}{c}\text { Bahasa } \\
\text { Indonesia }\end{array}$ & $\begin{array}{c}\text { Bahasa } \\
\text { Lio }\end{array}$ \\
\hline$* b$ & $\mathrm{~b}$ & $\mathrm{~b} ; \mathrm{mb}, \mathrm{bh}$ \\
\hline *d & d-; -d- & d-; nd-; dh- \\
\hline * $\partial$ & ә; a (suku ultima) & ә / E \\
\hline * $g$ & g- & g- ; gh-; ngg- \\
\hline & $-\mathrm{k}$ & - \\
\hline${ }^{*} \mathrm{~h}$ & (h)- & - \\
\hline$* q$ & $\mathrm{~h}$ & ? \\
\hline \multirow[t]{2}{*}{${ }^{*} \mathrm{R}$} & $\mathrm{r}$; & $\mathrm{r}-/ \mathrm{z}-$ \\
\hline & $-r$ & - \\
\hline * ay & ai & $-e$ \\
\hline * au & $\mathrm{au}$ & $-a$ \\
\hline * uy & $\mathrm{u}$ & - \\
\hline
\end{tabular}

Dalam Tabel 2 tersebut, terlihat bahwa bahasa Lio tidak memiliki konsonan yang berposisi pada akhir kata. Misalnya, kata akar dalam bahasa Indonesia jika diadaptasikan ke dalam bahasa Lio menjadi kata aka. Demikian pula, bahasa Lio tidak mengenal bunyi diftong sehingga diftong /ai/ dan /au/ dalam bahasa Indonesia cenderung menjadi $/$ e/dan /-a/dalam bahasa Lio, misalnya kata sampai (bahasa Indonesia) menjadi kata sampe (bahasa Lio)

\section{Tataran Kelompok Kata (Frasa)}

Berdasarkan data yang diperoleh, bahasa Lio mengenal frasa yang berstruktur D-M atau M-D dalam frasa benda, frasa kerja, dan frasa sifat. Sementara itu, frasa bilangan dalam ba- hasa Lio cenderung berstruktur M-D. Dengan demikian, pembelajaran frasa bahasa Indonesia lebih mudah karena kesamaan struktur tersebut. Perhatikan contoh perbandingan berikut.

\begin{tabular}{ll}
\hline \multicolumn{1}{c}{ Bahasa } & \multicolumn{1}{c}{$\begin{array}{c}\text { Bahasa } \\
\text { Lio }\end{array}$} \\
\hline pu'u nio (DM) & pohon nyiur kelapa (DM) \\
tui are (DM) & kulit padi (DM) \\
jara suka (DM) & kuda tunggang (DM) \\
uma rua (DM) & dua kebun (MD) \\
ika esa (DM) & satu ikan (MD) \\
\hline
\end{tabular}

\section{Tataran Kalimat}

Bahasa Lio tergolong jenis bahasa yang berstruktur SVO. Artinya, kalimat bahasa Lio berstruktur SPO, seperti halnya struktur kalimat bahasa Indonesia. Hanya saja, bahasa Lio tidak mengenal afiksasi dalam pembentukan kata jadian. Oleh sebab itu, struktur pada bahasa Lio memegang peranan penting untuk menentukan kata yang mengisi fungsi predikat kalimat. Dengan demikian, pembelajaran kalimat bahasa Indonesia akan lebih terbantu karena adanya kesamaan antara struktur bahasa Lio dan Indonesia. Perhatikan contoh perbandingan struktur kalimat berikut.

\begin{tabular}{|c|c|}
\hline Bahasa Lio & Bahasa Indonesia \\
\hline $\begin{array}{l}\text { Aku seo moko. } \\
\text { (SPO) }\end{array}$ & ) \\
\hline $\begin{array}{l}\text { Yuliana lae sekola. } \\
\text { (SP) }\end{array}$ & selum sekolah. \\
\hline $\begin{array}{l}\text { Aku ka'o di nua. } \\
\text { SPK) }\end{array}$ & $\begin{array}{l}\text { Saya lahir di desa. } \\
\text { (SPK) }\end{array}$ \\
\hline $\begin{array}{l}\text { Adik saya laki-laki. } \\
\text { SP) }\end{array}$ & Aji aku atakaki. (SP) \\
\hline $\begin{array}{l}\text { Aku ana sepususu. } \\
\text { (SP) }\end{array}$ & Aku a \\
\hline $\begin{array}{l}\text { Ne aku teka } \\
\text { utameta. (SPO) }\end{array}$ & $\begin{array}{l}\text { Ibu saya menjual } \\
\text { sayuran. (SPO) }\end{array}$ \\
\hline
\end{tabular}


Analisis Hasil Focus Group Disscussion (FGD)

FGD diadakan dalam rangka merumuskan model pembelajaran bahasa berbasis kultur berdasarkan adanya persamaan dan perbedaan antara bahasa yang satu dan yang lain. Peserta FGD adalah para ahli di bidang terkait, yaitu ahli linguistik perbandingan, pembelajaran, dan evaluasi pembelajaran. Hasil diskusi tersebut dapat dirumuskan sebagai berikut.

- Dapat dilakukan pembelajaran bahasa Indonesia berbasis bahasa dan kultur yang sudah dikenal para siswa. Jadi, siswa akan belajar B2 berdasar B1 yang sudah dikenalnya.

Contoh: Untuk siswa dengan bahasa dan kultur Lio, gambar wanita mengenakan sarung dan baju atas model baju bodo (Makasar), dia akan menamakan hal itu sebagai gambar ibu.

- Belajar bahasa tidak terlepas dari belajar kultur di tempat bahasa itu digunakan. Dengan demikian, materi pembelajaran bahasa Indonesia, berbeda-beda antara kultur satu dengan yang lain, meskipun pada dasarnya RPP-nya sama, SK dan KD yang dituju sama.

Contoh: Untuk siswa dengan bahasa dan kultur Lio, kalau ada gambar anak laki-laki, dia akan membaca tulisan di bawahnya, 'Ini Siberu' karena di Flores dengan kultur dan bahasa Lio tidak ada nama Budi, yang ada nama Siberu atau Michael.

- Buku pelajaran bahasa Indonesia disarankan tidak sama untuk seluruh Indonesia. Hendaknya, buku pelajar- an disesuaikan dengan kultur dan bahasa setempat. Dengan demikian, pelajaran akan lebih bermakna dan mudah dipahami siswa.

Contoh: Selama ini buku pelajaran bahasa Indonesia untuk kelas 1 SD menggunakan gambar dengan tulisan di bawahnya, 'Ini Budi', 'Ini ayah Budi', Ini ibu Budi' dan seterusnya. Hal itu tidak sesuai dengan kultur lain, mereka mengatakan itu buku pelajaran untuk orang Jawa, bahasa Indonesia Jawa.

- Pembelajaran B2 (bahasa Indonesia) dengan berpijak dari B1 (bahasa lokal) memungkinkan untuk dilakukan dengan pertimbangan, siswa belajar bahasa tidak perlu dua kali, yaitu pertama belajar bahasa pengantarnya, yaitu bahasa Indonesia, dan kedua, belajar materi bahasa Indonesia.

Contoh: Selama ini guru mengajarkan bahasa Indonesia dengan menggunakan bahasa pengantar bahasa Indonesia. Hal itu dilakukan sesuai dengan peraturan bahwa bahasa resmi yang digunakan di sekolah-sekolah adalah bahasa Indonesia. Namun, dalam praktik pembelajaran, sebenarnya tidak demikian sebab guru biasanya mengulang materi yang dijelaskan dengan bahasa lokal, bahasa yang sudah dikenal siswa. Dengan demikian, sebenarnya guru melakukan dua kali kerja, demikian pula siswa. Hal semacam itu tidak efektif, penguasaan siswa akan bahasa Indonesia menjadi lamban. Padahal, penguasaan bahasa Indonesia secara cepat itu penting mengingat semua mata pelajaran disampaikan dalam bahasa Indonesia. 
Model Pembelajaran Bahasa Indonesia Berbasis Kultur

Menurut Suyata (2006), bentuk pembelajaran multikultur dapat diawali dengan penggunaan strategi budaya dalam pembelajaran, pengenalan bahasabahasa majemuk, dan kajian-kajian yang bernuansa lokal. Dengan demikian, dalam hal pembelajaran bahasa, pengenalan bahasa Indonesia bagi yang berbahasa pertama bahasa daerah dan bahasa daerah bagi mereka yang berbahasa pertama bahasa Indonesia, beserta kultur yang menyertainya merupakan langkah awal bagi pembelajaran multikultur tersebut. Selanjutnya dikatakan, pada saat ini memahami pembelajaran sebagai suatu proses kultural dan berbasis kultur sangat direkomendasikan mengingat basis kultural diyakini mampu mencegah disintegrasi bangsa.

Pendekatan pendidikan multikultural bermacam-macam. Gibson (1998) mengemukakan empat pendekatan, yaitu (1) pendidikan yang berbeda secara kultural; (2) pendidikan tentang perbedaan-perbedaan budaya untuk saling memahami antar-budaya; (3) pendidikan demi pluralisme budaya; dan (4) pendidikan bikultural. Jadi, semua pendidikansesungguhnya suatu proses kultural. Paham inilah yang menjadfi inspirasi bagi ide untuk mengembangkan model pembelajaran multikultural di Indonesia dengan kondisi yang multietnik, multikultur, dan multibahasa.

Konsep pendidikan multukultural yang lain adalah pendekatan yang mengaitkan dengan konsep struktur sosial. Clark dalam Suyata (2006) menyebutkan lima jenis pendekatan pendidikan multikultural, yaitu (1) pengajaran ke- pada mereka yang berbeda secara kultural dengan titik berat pada kompensasi agar terjadi perubahan secara kultural; (2) pengajaran yang mendorong pentingnya hubungan manusia, mendorong siswa memiliki perasaan positif, toleransi, dan menerima orang lain; (3) pengajaran yang mendorong studi aneka budaya sebagai upaya mendorong persamaan kultural sosial; (4) pengajaran yang mengacu pada persamaan struktural sosial dan pluralisme kultural; dan (5) pendidikan multikultural yang sekalgus rekonstruksi sosial. Dengan demikian, pendidikan multikultural merupakan salah satu alternatif dalam membangun integrasi bangsa.

Bertitik tolak dari hasil FGD dipadu dengan studi kepustakaan yang dilakukan, disusun model pembelajaran bahasa Indonesia berbasis kultur. Model disusun berdasarkan kurikulum KTSP yang berlaku di tempat masing-masing. Berpijak dari kurikulum yang ada, dikembangkan RPP, kemudian disusun model pembelajaran tersebut.

Model disusun dalam bentuk CD. Pada CD diberikan gambar-gambar berwarna yang menarik sekaligus dilengkapi suara. Ada enam RPP yang diajarkan dalam enam pertemuan. Setiap pertemuan diawali dengan pretes dan diakhiri dengan postes. Pada akhir pembelajaran diberikan tes untuk materi 16. Berikut disampaikan berturut-turut model tersebut.

\section{Model Pembelajaran Kosakata}

Bahasa Lio sudah dikenal siswa sejak mereka lahir. Kontras antara bahasa Lio yang sudah mereka kenal dengan bahasa Indonesia akan memudahkan 
mereka belajar bahasa Indonesia, khususnya pada SD permulaan. Dalam pembelajaran kosakata, misalnya akan dapat diperkenalkan kosakata bahasa Lio dan padanannya dalam bahasa Indonesia.

Belajar bahasa tidak lepas dari belajar budaya. Belajar bahasa Lio dan Indonesia juga tidak lepas dari budaya Lio dan Indonesia. Dengan demikian, belajar bahasa Indonesia dapat dilakukan dengan titik tolak bahasa dan budaya Lio. Contoh berikut akan menjelaskan hal tersebut.

\begin{tabular}{lll}
\hline $\begin{array}{c}\text { Bhs. Lio- } \\
\text { Indo }\end{array}$ & \multicolumn{1}{c}{ Bahasa Lio } & Bahasa Indonesia \\
\hline $\begin{array}{l}\text { E - i-(r) } \\
\text { r-d }\end{array}$ & ae, sape, wange & air, sapi, wangi \\
rua $-\mathrm{b}$ & seriwu, tewu, & seribu, tebu, ubi, \\
& uwi, awu-awu & abu-abu \\
$\Phi-$ & ana, tana, jala, & anak, tanah, jalan, \\
konsonan & sabi, lau & sabit, laut \\
j-y & kaju & kayu \\
a- au & pisa & pisau \\
e- ai & take & tangkai \\
?- h & uja, ulu, pa'a & hujan, hulu, paha \\
\hline
\end{tabular}

\section{Model Pembelajaran Kelompok Kata (Frasa)}

Bahasa Indonesia dan Lio memiliki kemiripan dalam struktur frasa. Struktur frasa bahasa Lio pada umumnya berpola D-M yang sama dengan struktur frasa bahasa Indonesia pada umumnya. Hal tersebut dapat memperlancar dan mempermudah para siswa yang berlatar bahasa dan budaya Lio untuk belajar bahasa Indonesia permulaan. Kesamaan atau kemiripan struktur frasa antara bahasa Lio dan Indonesia dapat diberikan contoh sebagai berikut.

\section{Bahasa Lio}

kira doi (D-M)

wesa jala (D-M)

leja lo'o (D-M)

manu co aku(D-M)

ina toja (M-D)

sena raka (M-D)

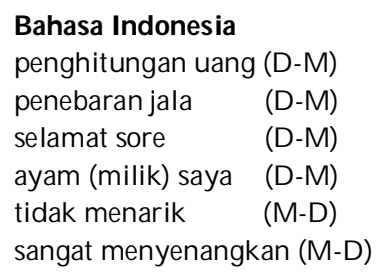

Selain kemiripan tersebut, pada jenis frasa tertentu terdapat perbedaan antara struktur frasa bahasa Lio dan Indonesia. Hal ini terjadi pada frasa atributif yang unsur pusatnya berupa kata benda dan unsur atributnya berupa bilangan. Misalnya, frasa 'dua bulan' dalam bahasa Indonesia berstruktur M-D, sedangkan dalam bahasa Lio menjadi 'wula rua' berstruktur D-M.

\section{Model Pembelajaran Kalimat}

Seperti halnya pembelajaran kelompok kata, pembelajaran kalimat menggunakan terjemahan kata per kata karena struktur kalimat bahasa Lio dan Indonesia tidak berbeda. Oleh karena itulah, siswa yang berlatar bahasa dan budaya Lio sangat terbantu ketika belajar bahasa Indonedsia permulaan. Hal ini dapat diberikan contoh berbandingan struktur kalimat antara bahasa Lio dan bahasa Indonesia seperti berikut.

$\begin{array}{ll}\text { Bahasa Lio } & \text { Bahasa Indonesia } \\ \text { Kau deo sura aku. } & \text { Kau membawa suratku. } \\ \text { Kai mera leka sa'o ghea. } & \text { Dia tinggal di rumah itu. } \\ \text { Aku ana sepususu. } & \text { Aku anak bungsu. } \\ \text { Yuliana belum sekolah. } & \text { Yuliana lae sekola. } \\ \text { Aji aku atakaki. } & \text { Adik saya laki-laki. }\end{array}$

Perlu ditambahkan di sini bahwa bahasa Lio tidak mengenal imbuhan, baik awalan, sisipan, maupun akhiran, seperti yang terjadi dalam bahasa Indonesia. Oleh sebab itu, urutan kata memiliki peran penting dalam penerjemahan kalimat bahasa Lio ke dalam 
kalimat bahasa Indonesia. Perhatikan contoh berikut.

$\begin{array}{ll}\text { Bahasa Lio } & \text { Bahasa Indonesia } \\ \text { seo moko } & \text { menggoreng pisang } \\ \text { tenu ika } & \text { membakar ikan } \\ \text { mula are } & \text { menanam padi } \\ \text { kira doi } & \text { menghitung uang }\end{array}$

Sementara itu, struktur frasa 'moko seo' diterjemahkan ke dalam frasa bahasa Indonesia menjadi 'pisang goreng', frasa 'ika tenu' menjadi 'ikan bakar'.

\section{HASIL UJI MODEL PEMBELAJARAN BAHASA INDONESIA BERBASIS KULTUR}

Model pembelajaran bahasa Indonesia berbasis kultur diujicobakan di Ende, Flores, NTT dengan kultur bahasa Lio. Uji model dilakukan dua tahap, (1) validasi isi oleh expert dan (2) validasi pengguna oleh guru dan siswa. Berikut hasil uji model tersebut.

\section{Validasi Isi Model oleh Expert}

Isi pembelajaran divalidasi oleh ahli bahasa Lio, ahli pembelajaran multikultur, dan ahli media CD. Hasil validasi mengatakan model pembelajaran bahasa Indonesia berbasis kultur dari segi isi cukup baik dan dapat digunakan dalam pembelajaran di sekolah. Namun, ada peringatan dari ahli media terkait beban listrik yang diperlukan untuk penggunan CD. Di tempat yang beban listriknya kurang memadai, kemungkinan CD ini tidak dapat dioperasikan.

\section{Validasi Model oleh Pengguna}

Validasi model dilakukan oleh pengguna (oleh guru dan siswa) di SD 5 Ndona, Ende, Flores, NTT. Latar belakang siswa SD kelas 1 ada yang berasal dari TK dan ada pula yang tanpa melalui TK. Orang tua siswa SD V Ndona adalah petani dan nelayan. Hasil uji model sebagai berikut.

Pembelajaran dilakukan selama November 2009 yang dilakukan oleh guru kelas 1. Peralatan LCD, laptop, buku, dan alat tulis untuk guru dan siswa disediakan peneliti. Selama pembelajaran berlangsung, ada seorang teknisi yang membantu operasional peralatan dan seorang guru lain yang membantu mengamati dan mencatat jalannya pembelajaran di kelas.

Dari catatan lapangan (field note), terungkap bahwa pada pertemuan awal, siswa masih belum terbiasa dengan model pembelajaran dengan $C D$ tersebut. Hal itu terlihat dari hasil tes yang rata-rata masih kurang baik. Namun, pembelajaran selanjutnya bisa lebih lancar dan bahkan pada akhir pembelajaran siswa justru menyukai model pembelajaran semacam itu. Suasana kelas menjadi hidup dan siswa bergairah untuk belajar. Motivasi siswa meningkat dengan model pembelajaran semacam itu. Hal itu terbukti dari hasil tes akhir yang meningkat nilainya dengan rata-rata memenuhi standar kelulusan minimal (KKM).

Hasil tes pembelajaran dengan model tersebut dapat diamati pada tabel berikut. 
Tabel 3: Hasil Uji Model Pembelajaran di SD Ndona 5, Ende, Flores Barat

\begin{tabular}{cccllc}
\hline No. & $\begin{array}{c}\text { Pertemuan } \\
\text { ke- }\end{array}$ & $\begin{array}{c}\text { Jumlah } \\
\text { Siswa }\end{array}$ & \multicolumn{1}{c}{ Hasil Pretes } & Hasil Postes & $\begin{array}{c}\text { Indeks } \\
\text { Sensitivitas }\end{array}$ \\
\hline 1. & 1 & 28 & $3,0(60 \%)$ & $3,53(70,6 \%)$ & 0,02 \\
2. & 2 & 28 & $3,17(60,34 \%)$ & $3,6(72,0 \%)$ & 0,02 \\
3. & 3 & 28 & $3,03(60,06 \%)$ & $3,73(74,0 \%)$ & 0,03 \\
4. & 4 & 28 & $2,96(59,20 \%)$ & $3,82(76,4 \%)$ & 0,03 \\
5. & 5 & 28 & $3,03(60,06)$ & $3,82(76,4 \%)$ & 0,03 \\
6. & 6 & 28 & $3,35(67,5 \%)$ & $3,86(75,2 \%)$ & 0,02 \\
\hline
\end{tabular}

Pada tabel hasil uji model pembelajaran di SD Ndona 5 Flores tersebut dapat diketahui bahwa indeks sensitivitas dalam posisi positif semua. Hal ini berarti pembelajaran yang dilakukan memiliki dampak yang baik bagi siswa yang belajar bahasa Indonesia permulaan di SD Ndona 5 Flores. Dengan demikian, model pembelajaran yang diujikan cukup baik dan dapat digunakan guru dalam pembelajaran bahasa Indonesia permulaan.

\section{KESIMPULAN}

Bahasa Lio dan bahasa Indonesia memiliki banyak kemiripan, baik dalam sistem fonem, kelompok kata, maupun struktur kalimat. Oleh sebab itu, siswa yang berlatar belakang bahasa dan budaya Lio lebih banyak terbantu ketika mereka belajar bahasa Indonedsia tingkat awal. Meskipun demikian, guru perlu memahami bahwa selain ada kemiripan, antara bahasa Lio dan Indondesia terdapat perbedaan, yakni pola suku kata bahasa Lio hanya $\mathrm{V}$ dan KV sehingga tidak ada konsonan di akhir su$\mathrm{ku}$ atau akhir kata, sedangkan pola suku kata dalam bahasa Indonesia ada delapan jenis $(\mathrm{V}, \mathrm{KV}, \mathrm{VK}, \mathrm{KVK}$. KKV, VKK, KKKV, KKKVK).
Pola struktur frasa antara bahasa Lio-Indonesia memiliki banyak kemiripan, yakni struktur D-M dan M-D. Bahkan, struktur kalimat pada kedua bahasatersebutmemiliki kesamaan, yakni struktur kalimat SVO. Hanya, dalam bahasa Indonesia, frasa yang menunjukkan jumlah benda, kata bilangan berposisi di depan benda, sedangkan dalam bahasa Lio, kata bilangan berposisi setelah kata benda. Seperti, 'dua anak' (Indonesia) - ana rua (Lio).

Oleh karena banyak kemiripan dan kesamaan antara bahasa Lio-Indonesia, baik dalam sistem fonem-kata, pola frasa,maupun struktur kalimat/klausa, model pembelajaran kontrastif Lio-Indonesia cocok digunakan untuk pembelajaran bahasa Indonesia permulaan bagi siswa yang berlatar belakang bahasa dan budaya Lio.

\section{UCAPAN TERIMA KASIH}

Pelaksanaan penelitian ini dibantu oleh berbagai pihak, khususnya dalam pemerolehan data kebahasaan dan pelaksanaan ujicoba model. Untuk itu, penulis menyampaikan rasa terima kasih kepada Bapak Simon Simo, Bapak Michael Weru, Ibu Maria Martakia Nika, Ibu Sisilia Tanga, dan Ibu Anastasia Mary sebagai informan pemakai 
bahasa Lio. Rasa terima kasih disampaikan pula kepada Ibu Grasiana Wunu, Ibu Yulita Eme, dan Ibu Emiliana Momi yang telah membantu peneliti dalam pelaksanaan ujicoba model di SD Ndona 5 Ende, Flores Barat.

\section{DAFTAR PUSTAKA}

Crowley, Terry. 1997. An Introduction to Historical Linguistics. Suva University of Papua, New Guinea.

Depdiknas. 2003. Undang-Undang Pendidikan.No. 20 Tahun 2003. Jakarta: Depdiknas.

Dhanawati, Ni Made. 2002. "Variasi Dialektal Bahasa Bali di Daerah Transmigrasi Lampung Tengah". Disertasi. Universitas Gajah Mada.

Gibson, Joseph. 1998. "Education and Plutalism" Thomas. Labelle (ed) Education and Deve-lopment : Latin America and the Caribbean. Angelos: Latin American Center, UCLA.

Harimurti, Kridalaksana. 2007. “Bahasa dan Linguistik". dalam Pesona Bahasa: Langkah Awal Memahami Linguistik. Jakarta: Gramedia Pustaka Utama.

Kusworo, Budi. 2006. "Pengendalian Mutu Pendidikan Dasar dan Menengah". Jurnal Puspendik Vol 3/ No.1.
Mbete, Aron Meko dkk. 2006. Khazanah Budaya Lio-Ende. Ende: Pustaka Larasan.

Mbete, Aron Meko dan Petrus Wake. 2006. Bahan Pembelajaran Muatan Lokal Berbasis Kompetensi: Kelas III SD/MI Kabupaten Ende. Ende: Pustaka Larasan.

Parera, Yos Daniel. 1998. Linguistik Edukational: Metode Pembelajaran Bahasa, Analisis Kontrastif Antar-bahasa, Analisis Kelasalahan Berbahsa. Jakarta: Erlangga.

Setiawati D. dan Kushatanti. 2007. "Aspek Kognitif Bahasa" dalam Pesona Bahasa: Langkah Awal Memahami Linguistik. Jakarta: Gramedia Pustaka Utama.

Suyata, Pujiati. 2007. "Status Isolek Bahasa Jawa Sala-Yogya dan Implikasinya bagi Bahasa Standar". Litera Vol 1NNo. 1. Hal. 1-15.

Tyron, Darrell. 1998. "Proto-Austronesian and the Mayor Austronesia Subgroups" dalam Bellwood, Peter, dkk (1998) The Austronesian: Historical and Comparative Perspective. Canberra: ANU Printing. 